\title{
Hysteresis of White Adipose Tissue
}

\author{
Alain Géloën ${ }^{*}$, Hédi Soula1,2,3, Lilas Hadji1 ${ }^{1}$ Emmanuelle Berger1 \\ ${ }^{1}$ Université de Lyon, CARMEN INSERM U1060, INSA-Lyon, F-69621, Villeurbanne, France \\ ${ }^{2}$ IXXI Complex Systems Institute, Lyon, France \\ ${ }^{3}$ EPI BEAGLE INRIA F-69621, Villeurbanne, France \\ Email: ${ }^{*}$ alain.geloen@insa-lyon.fr
}

Received 11 September 2015; accepted 25 October 2015; published 28 October 2015

Copyright (C) 2015 by authors and Scientific Research Publishing Inc.

This work is licensed under the Creative Commons Attribution International License (CC BY). http://creativecommons.org/licenses/by/4.0/

(c) (i) Open Access

\section{Abstract}

Objective: This study was performed to analyze the modifications within adipose tissue during calorie restriction and more specifically to state whether hysteresis occurs during fat mass reduction. Method: Rats male Wistar increased their body weight by $130 \mathrm{~g}$ under control conditions and were then submitted to a calorie restriction (CR) at $30 \%$ or $60 \%$ of control. Experiment has been stopped when the body weight of the group $\mathrm{CR60 \%}$ returned back to its initial value. Samples of retroperitoneal adipose tissue were collected by biopsies along the study. Adipose cell size was analyzed using multisizer IV (Beckman Coulter) to determine the size distribution curves during natural growth and after calorie restriction. Results: After $\mathrm{CR60 \%}$, body weights and adipose tissue masses were similar to the ones at the beginning of the experiment. Adipose cell size distribution curve was shifted to the left compared to the one of initial control. Adipose cell sizes were significantly lower after CR60\% than those of control at the beginning of the experiment. Conclusions: These results state for the first time that hysteresis occurs in white adipose tissue after calorie restriction. The composition of adipose tissue after calorie restriction was significantly different than the one of initial control. After significant weight loss, organisms must be considered as different from the initial controls, they are most likely governed by different regulations which will have to be identified.

\section{Keywords}

Adipocyte Size, White Adipose Tissue, Calorie Restriction, Hysteresis

\section{Introduction}

White adipose tissue is the main site of energy storage as triglycerides. It is nowadays considered as a major

\footnotetext{
${ }^{*}$ Corresponding author.
} 
regulator of many physiological regulations of critical importance such as food intake, energy expenditure, insulin sensitivity and even immune system through the numerous adipokines it produces [1]. Adipocytes are the cells within organism having the highest hability to change their size. Indeed a 10 times change in diameter results in a 1000 times change in volume. Such changes in size may occur during the setting of obesity but also during shortage in energy intake. Numerous studies have suggested that the size of adipose cells has major incidences on their physological functions. It is the case for lipolysis [2] [3], lipogenesis activity [4], adrenoceptors expression [5], glucose metabolism [6] and adipokines secretion [7] [8]. Nevertheless, how cell sizes change during body weight variations remains poorly documented. The aim of the present work was to study cell size changes during normal growth and caloric restriction to get insights on the physiological capabilities of adipose cells to change their sizes. It was specifically designed to test the hypothesis of hysteresis of adipose tissue. Hysteresis is the property of a system that returns back to an initial state through a route that is not superposable to the one utilized to reach a final state. It is known that the number of adipose cells can hardly decrease during fasting [9] or even type I diabetes [10]. Besides, it is also known that adipose cell number increases throughout lifespan when adipose tissue expends [11]. We may then conclude that during caloric restriction, the size of adipose cells will decrease but the number of adipose cells will remain unchanged. Considering adult at $\mathrm{T} 0$, after a growing period, calorie restriction will decrease body weight back to the initial T0 value. Adipose tissues should as well return to initial values. If the concept of hysteresis is true, after calorie restriction animals should have the same body weight, the same adipose tissues masses, but the size of adipocyte should be significantly decreased compared to the one at T0. Epididymal, subcutaneous and retroperitoneal adipose tissues have been studied to state whether hysteresis occurs similarly in different localizations.

\section{Materials and Methods}

\subsection{Animals}

Adult male Wistar rats [Harlan Gannat, France] were housed in an air-conditioned room with a controlled environment $\left[24^{\circ} \mathrm{C} \pm 1^{\circ} \mathrm{C}\right]$ under a $12 \mathrm{~h}$ light and dark cycle with free access to food [3.2 kcal/g, 65\% carbonhydrates, $11 \%$ lipids, $24 \%$ proteins [wt/wt], AO3, SAFE, Augy, France] and tap water.

\subsection{Experimental Protocol}

Experimental protocol was done on twenty six rats weighting $321.5 \pm 2.6$ g. To avoid individual variations in adipose tissue masses and adipose cell size, biopsies of RWAT were performed. The advantage of biopsies is that it allowed to followed the changes in adipose cell sizes on the same animal during the time-course of the experimental protocol. Biopsies of RWAT were performed on 18 rats at T0 $=$ day 0 . Animals were anesthetized with isoflurane. Skin was disinfected with alcohol and betadin. A small incision was realized on the back of the animals. A fragment from 80 to $100 \mathrm{mg}$ of retroperitoneal adipose tissue was taken under sterile conditions. The muscle layer and then the skin were stitched and disinfected. A disadvantage of biopsies is that it is not possible to precisely measure the weight of adipose tissues. For that reason four animals were sacrificed at the beginning of the experiment corresponding to control T0 [323.2 $\pm 6.5, \mathrm{n}=4$ ] and at $\mathrm{T} 1[443.7 \pm 11.1 \mathrm{~g}, \mathrm{n}=4]$. Animals were fed ad libitum a standard diet. After 37 days [T1] of normal growth, animal body weights were $452.4 \pm 6.0$ $\mathrm{g}[\mathrm{n}=22]$. A second biopsie of RWAT was practiced at $\mathrm{T} 1$ = day 37, on 18 animals. Then, they were randomly divided into three groups: control fed ad libitum, calorie restricted à $30 \%$, calorie restricted at $60 \%$. After 22 days, rats submitted to $60 \%$ of caloric restriction had lost $100 \mathrm{~g}$, their body weights were not significantly different from the one of control at T0. Rats submitted to a caloric restriction of $30 \%$ kept a stable body mass [438.2 \pm 25.4 ] while control weighed $540.6 \pm 39.5$. Rats were sacrificed by a lethal injection of pentobarbital and dissected.

\subsection{Blood Samples and Tissues Dissections}

Blood was rapidly withdrawn from cardiac puncture on heparinized tubes, centrifuged $5 \mathrm{~min}$ at $4000 \mathrm{~g}$ to prepare plasma. White adipose tissues [WAT] from three different anatomical depots: epididymal [EWAT], retroperitoneal [RWAT] from both sides, and subcutaneaous [SCWAT] from only one side were dissected out, according to anatomical landmarks and weighted. One sample of each tissue was fixed for the measure of cellularity, another sample was snap frozen in liquid nitrogen and stored at $-80^{\circ} \mathrm{C}$. 


\subsection{Cellularity Study: Measurement of Adipocyte Size}

The method for measuring adipose cell size has been recently described [12]. Small adipose tissue samples (50 $90 \mathrm{mg}$ ) from each depot were rinsed twice with $\mathrm{NaCl} 0.9 \%[\mathrm{w} / \mathrm{v}]$ at $37^{\circ} \mathrm{C}$, twice in $50 \mathrm{mM} \mathrm{2,4,6-trimethylpyri-}$ dine $/ \mathrm{NaCl} 0.9 \%$ and fixed in $0.12 \mathrm{M}$ osmium tetroxide/50 mM 2,4,6-trimethylpyridine/ $\mathrm{NaCl} 0.9 \%$ [Sigma Aldrich, Saint Quentin Fallavier, France] for 96 hours at room temperature. Samples were washed with saline for $24 \mathrm{~h}$, then the saline was replaced by $10 \mathrm{~mL}$ of $8 \mathrm{M}$-urea for $72 \mathrm{~h}$ with occasional swirling to liberate the cells. Samples were filtered to remove undegraded piece of tissue and then washed with $0.01 \%$ TRITON X-100 [v/v] in $\mathrm{NaCl}$ buffer. Then the supernatant was discarded and cells were resuspended in glycerol. Cell suspensions were diluted. The adipocyte size distribution was measured using a Beckman Coulter Counter Multisizer IV with a $400 \mu \mathrm{m}$ aperture allowing an effective aperture of $20-240 \mu \mathrm{m}$. Data were expressed as particle diameters. Cell-size distributions were drawn from measurement of at least 20,000 cell diameters per adipose tissue.

Adipose cell size repartition is bimodal with two cell populations distinguishable according to their size. These two populations having small size and much larger size, are separated by the nadir, which is the size at which the cell frequency is the lowest. The mode is the size at which the cell frequency is the largest. The width refers to the width of the gaussian curve at half the maximum drawn from the frequency of diameters of the larger cell population. To calculate the critical parameters of cell size distribution like mode, width and nadir, cellularity histograms were fitted against a sum of two exponentials [to describe small adipocytes] and a gaussian [for bigger adipocytes]. A simple Levenberg-Marquardt algorithm was used to minimize quadratic error.

$$
X^{2}(a, \tau, m, s)=\sum_{k}|f(k d r, a, \tau, m, s) d r-h(k)|^{2}
$$

with $k$ 's being bins indices, $d r$ the bins width and

$$
f\left(r, a_{1}, \tau_{1}, a_{2}, \tau_{2}, m, s\right)=a_{1} \exp \left(-\frac{(r-20)}{\tau_{1}}\right)+a_{2} \exp \left(-\frac{(r-20)}{\tau_{2}}\right)+\left(1-a_{1}-a_{2}\right) \frac{1}{\sqrt{2 \pi s^{2}}} \exp \left(-\frac{|r-m|^{2}}{2 s^{2}}\right)
$$

The mode of the distribution refers to the parameter $\mathrm{m}$ and the width as $\mathrm{s}$. The nadir of the distribution is found numerically by looking for the root of the derivative of the fit [13] [14].

\subsection{Statistical Analysis}

Data are expressed as means \pm standard error of the mean or standard deviation. Statistical analysis were performed with Stat View 4.5 software for Windows, the data were analyzed using one way ANOVA following by Fisher's protected least significance difference [PLSD], post hoc test. Statistical significance was accepted at $\mathrm{p}<$ 0.05 .

\subsection{Ethics}

All experiments were performed according to the guidelines laid down by the French Ministère de l'Agriculture [ ${ }^{\circ} 87$ - 848] and the European Union Council Directive for the Care and Use for the Laboratory Animals of November $24^{\text {th }}, 1986$ [86/609/EEC]. AG [n69266332] hold a special license to experiment on living vertebrates issued by the French Ministry of Agriculture and Veterinary Service Department.

\section{Results}

\subsection{Evolution of Body Mass}

Initial body mass of the animals was $321.5 \pm 2.6 \mathrm{~g}[\mathrm{n}=26]$. Four animals were sacrificed at the beginning of the experiment corresponding to control T0 [323.2 $\pm 6.5, \mathrm{n}=4]$. A first biopsie of RWAT was practiced on the remaining animals. After 37 days of ad libitum feeding, animals body mass were $452.4 \pm 6.0 \mathrm{~g}[\mathrm{n}=24]$. Four rats were sacrificed corresponding to control T1 [443.7 $\pm 11.4 \mathrm{~g}, \mathrm{n}=4]$. From T0 to T1 body mass growth of animals was $130 \mathrm{~g}$. A second biopsie of RWAT was practiced on the remaining animals. Then they were divided into 3 groups, either ad libitum fed or $30 \%$ or $60 \%$ calorie restriction. After 22 days, control animals weighed $540.6 \pm 39.5$ g. From T2 to T3, body weight of animals submitted to $30 \%$ calorie restriction remained constant while animals submitted to $60 \%$ calorie restriction lost 100 g [353.0 \pm 25.8 g, Figure 1]. In ad libitum fed rats, 


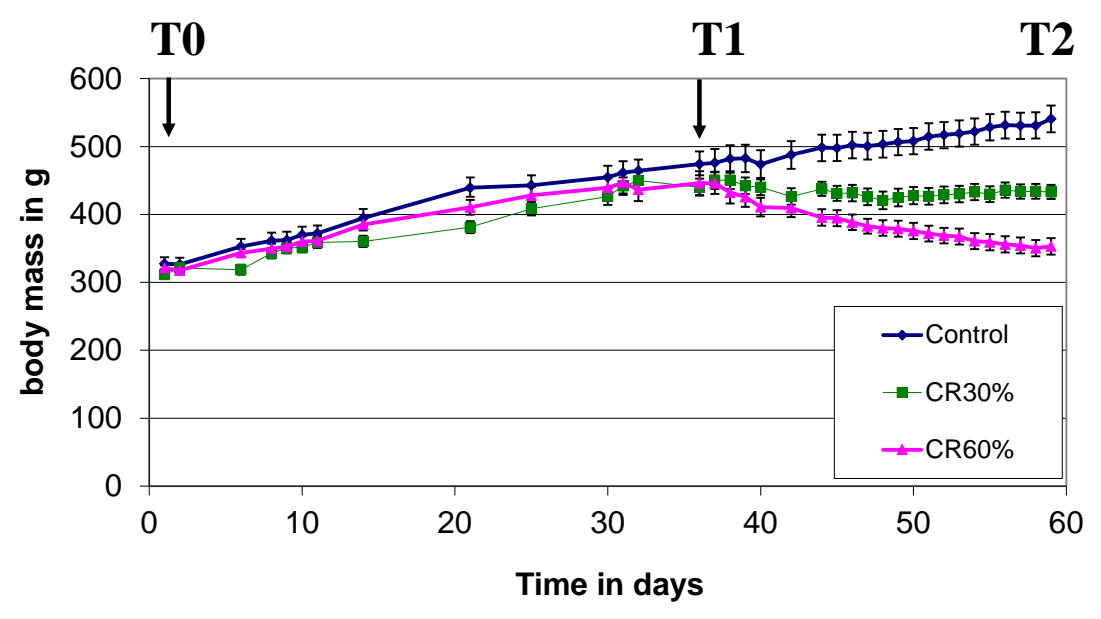

Figure 1. Evolution of body weights during the experimental protocol. After 37 days of ad libitum feeding, rats were divided into 3 groups, either fed ad libitum [control] or $30 \%$ or $60 \%$ calorie restricted [respectively CR30\% and CR60\%]. Adipose tissue biopsies and sacrifices have been performed at $\mathrm{T} 0$ and $\mathrm{T} 1$.

the sum of adipose tissues [EWAT, RWAT and SCWAT] was $8.6 \pm 0.4 \mathrm{~g}, \mathrm{n}=4$ at T0, $16.92 \pm 1.4$ at T1 and $24.8 \pm 4.5 \mathrm{~g}$ at T2. In $30 \%$ calorie restricted animals it was $18.2 \pm 1.5 \mathrm{~g}$ and $9 \pm 1.9 \mathrm{~g}$ in $60 \%$ calorie restricted animals. Body weights and adipose tissue weights were similar in control T0 and CR60\% T2. The weights of individual adipose tissue followed that evolution [Figure 2]. EWAT and RWAT grew faster than SCWAT.

\subsection{Adipose Tissue Composition}

Concerning RWAT, the size repartition curves have been built from adipose tissue obtained by biopsies coming from the same animals, at different times: T0, T1 and T2. Thus they represent the true evolution of cell sizes during the time course of the experiment. The normal growth in ad libitum fed rats resulted in a slight right shift of the curve [Figure 3(a)]. The mode and the mean increased significantly from T0 to T2, while nadir and width did not change significantly [Table 1]. The effects of 30\% calorie restriction were very limited. It stabilized body weight [Figure 1] and adipose tissue masses [Figure 2]. Concerning the repartition cell size curve, only the width was significantly lower than the one of control $\mathrm{T} 1$ and became similar to the initial control $\mathrm{T} 0$. The mode, the nadir and the mean remained similar than the one of control T1. The "mean" remained significantly higher in 30\% calorie restriction compared with T0 [Table 1, Figure 3(b)].

The most significant result of the present study is that the "mean" and the "mode" after $60 \%$ calorie restriction were significantly lower than the one of initial control T0 [Table 1]. Indeed the cell size repartition curve of T2 CR60\% is shifted to the left compare to the one of Control T0 [Figure 4(a)]. A similar result was observed for SCWAT, although in that case the tissue have been collected on different animals [Figure 4(b)]. On the opposite no difference was observed in EWAT between T2 CR60\% and Control T0 [Figure 4(c)].

\section{Discussion}

The most important result of the present study is the evolution of cell size during food restriction. Although, it may be obvious that food restriction results in a loss of white adipose tissue mass, and most likely in adipose cell size, the evolution of cell size during food restriction has never been extensively studied. The aim of the present study was to test whether hysteresis occurs in adipose tissue during calorie restriction. Results show that after a period of normal growth [T0 to T1] a calorie restriction causing the reduction of body weight to the initial value resulted in similar adipose tissue mass but with a significant reduction of adipose cell sizes. The fact that animals at T0 control and T2 CR60\% have the same body weight, the same adipose mass but significantly decreased adipose cell sizes, is the signature that hysteresis occurs in adipose tissue [RWAT and SCWAT]. In theory, the reduction of adipose mass may occur through only two mechanisms either the reduction of cell number or the reduction of adipose cell size. The fact that adipose cell number can hardly decrease is well document. Indeed, severe food restriction and even diseases causing strong losses of body weight rarely result in a 


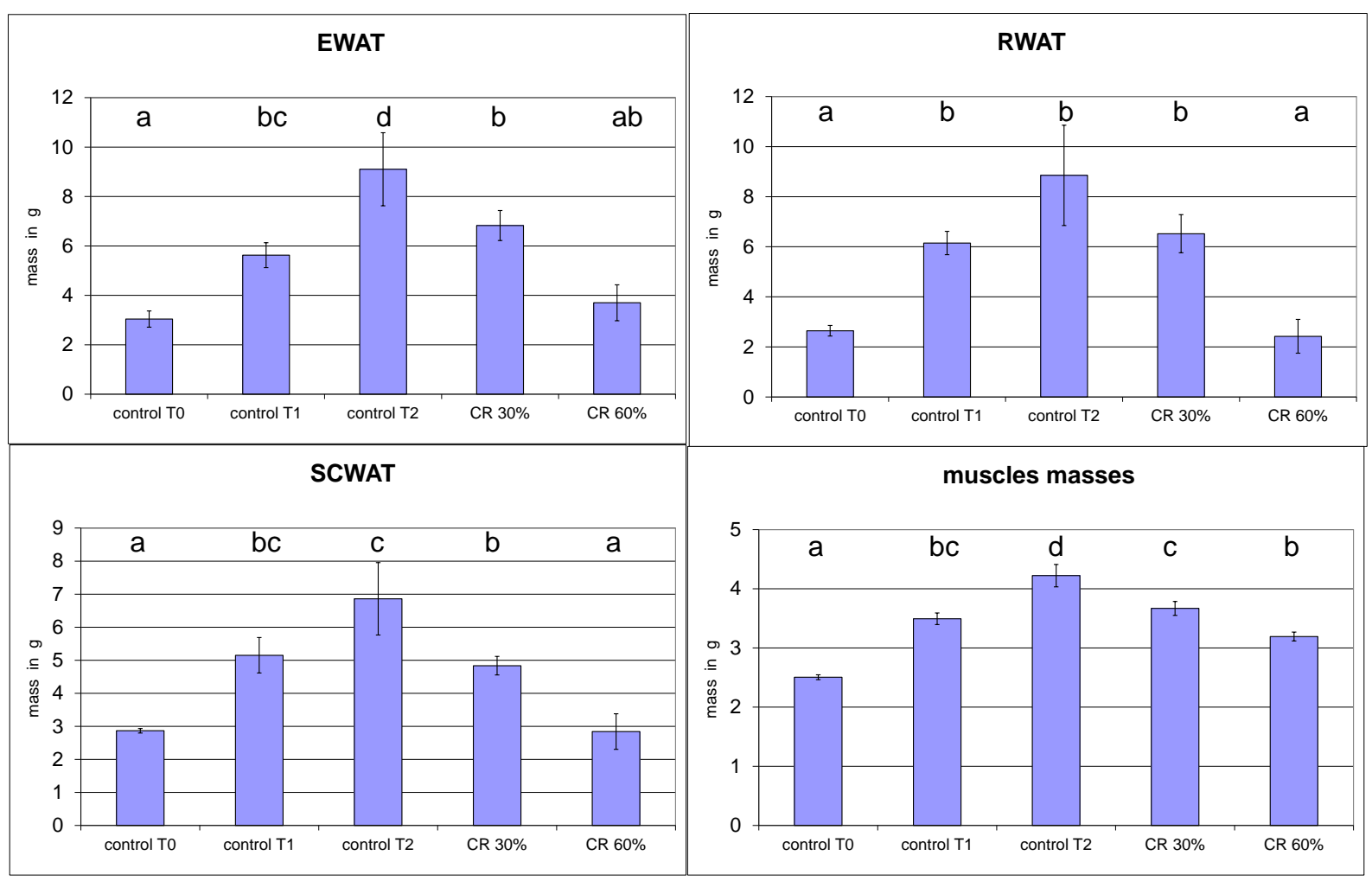

Figure 2. Evolution of epididymal, retroperitoneal subcutaneous adipose tissue weights and muscles masses [sum of gastrocnemius, soleus, tibialis, extensor digitorum longus].

decreased adipose cell number [10] [15]. The only possibility to decrease adipose tissue mass is then to reduce adipose cell size. This is what is observed in the present study. From T0 to T1, adipose cell size increased as likely cell number increased [11]. The only way to reduce adipose tissue being a reduction of adipose cell size, the resultant is hysteresis. Animals have the same fat mass but not the same composition of adipose tissue. It is because the number of adipose cells increased during growth that hysteresis happens. Otherwise, one would observe only changes in adipose cell size, increased during growth and back to initial values for a given body weight. In the present study, hysteresis has been observed only in RWAT and SCWAT, not in EWAT, although the changes in adipose tissue mass where in the same range in EWAT than in other adipose tissues. The main reason for that is that there is a cell size gradient from the proximal to the distal sites in EWAT [16]. During animal growth, cell proliferation occurs mainly at the distal part of EWAT. Since most of the EWAT tissue samples have been taken in the proximal EWAT part, it is rather logical not to observe hysteresis in that particular case. It does not mean that hysteresis does not occurs in EWAT. Cell size gradient within EWAT will have to be taken into account in further studies. The $30 \%$ calorie restriction had very limited effects on the cell size repartition curve, suggesting that the reduction in adipose tissue mass has to be strong enough to observe a significant effect on adipose cell sizes. CR30\% stabilized body mass and adipose tissue mass, which means that energy intake was equal to energy expenditure. Under these conditions, the cell size repartition curves were very similar between Control T1 and CR30\%. The CR30\% curve was only slightly reshaped compared to the one of control T1, mainly because the width decreased significantly. It is not easy to explain why the width decreased resulting from a limited but significantly different cell size repartition [Figure 3(b)]. The present results do not give insight on how much the body weight and adipose tissue mass must be reduced to observe hysteresis. Considering that a 100 g reduction in body weight in rats [-22\%] produced a $27 \%$ decrease of the mode, it is obvious that hysteresis can be observed for lower reduction in body mass. Important loss of body weight may occur in Humans, as for example after diet restriction or bariatric surgery, suggesting that hysteresis most likely occurs in humans, although it has never been described so far.

The occurrence of hysteresis in white adipose tissue has several implications. Since the number of adipose cells does not decrease during calorie restriction, it means that adipose tissue can rapidly increase in case of positive 


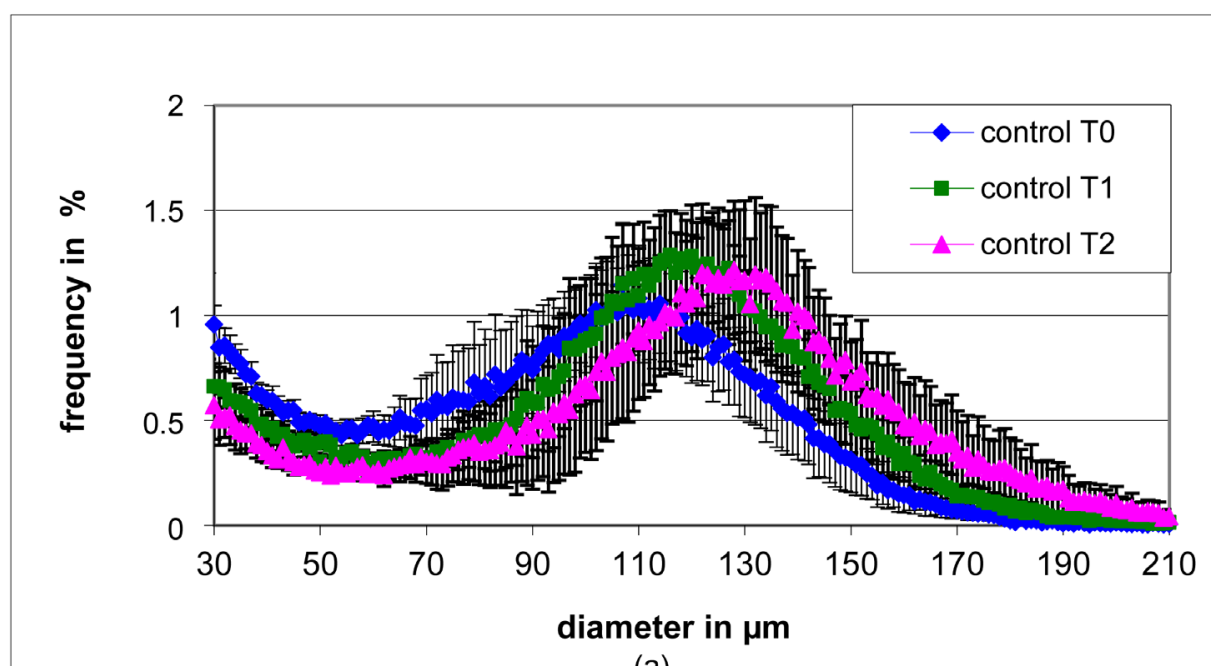

(a)

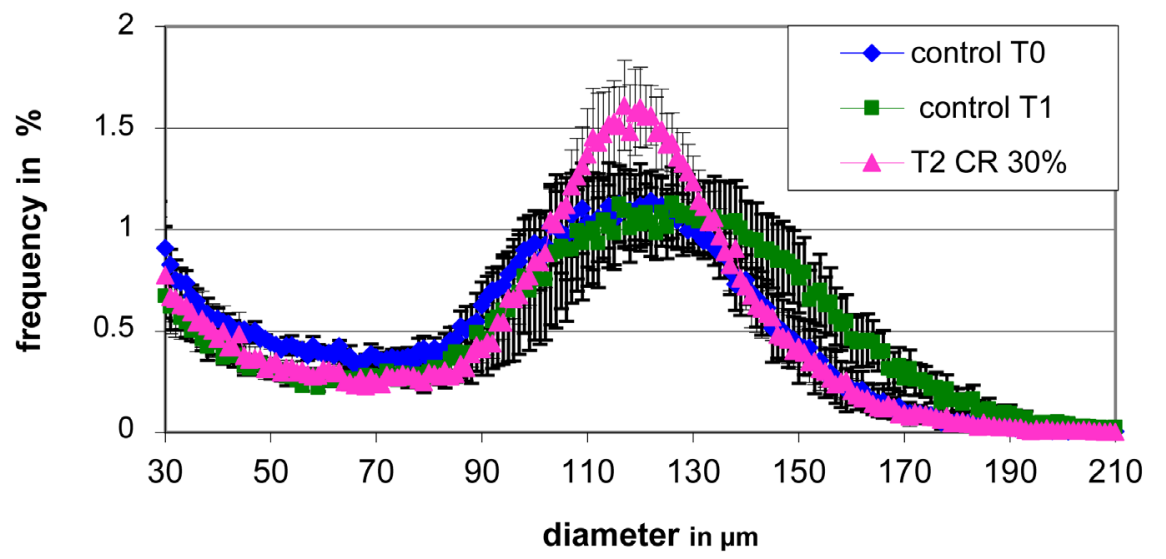

(b)

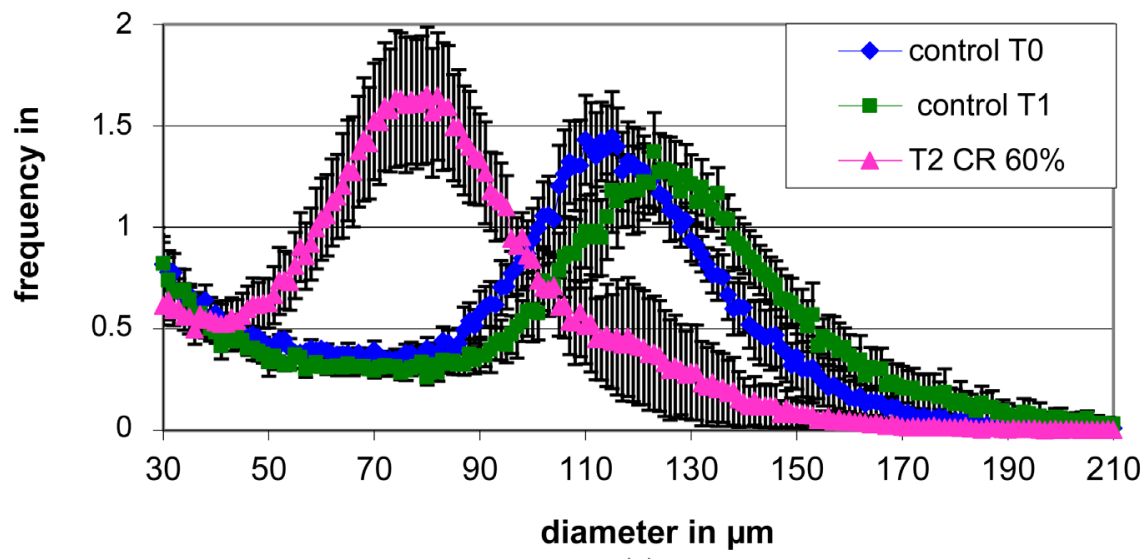

(c)

Figure 3. Evolution of retroperitoneal adipose cell size repartition. Animals have been fed either ad libitum (a) or $30 \%$ (b) or $60 \%$ (c) calorie restricted at T1 [n = 5 - 6/group]. Since adipose tissue samples have been collected by biopsies, each graph represents the evolution of adipose cell size repartition in the same animals. 

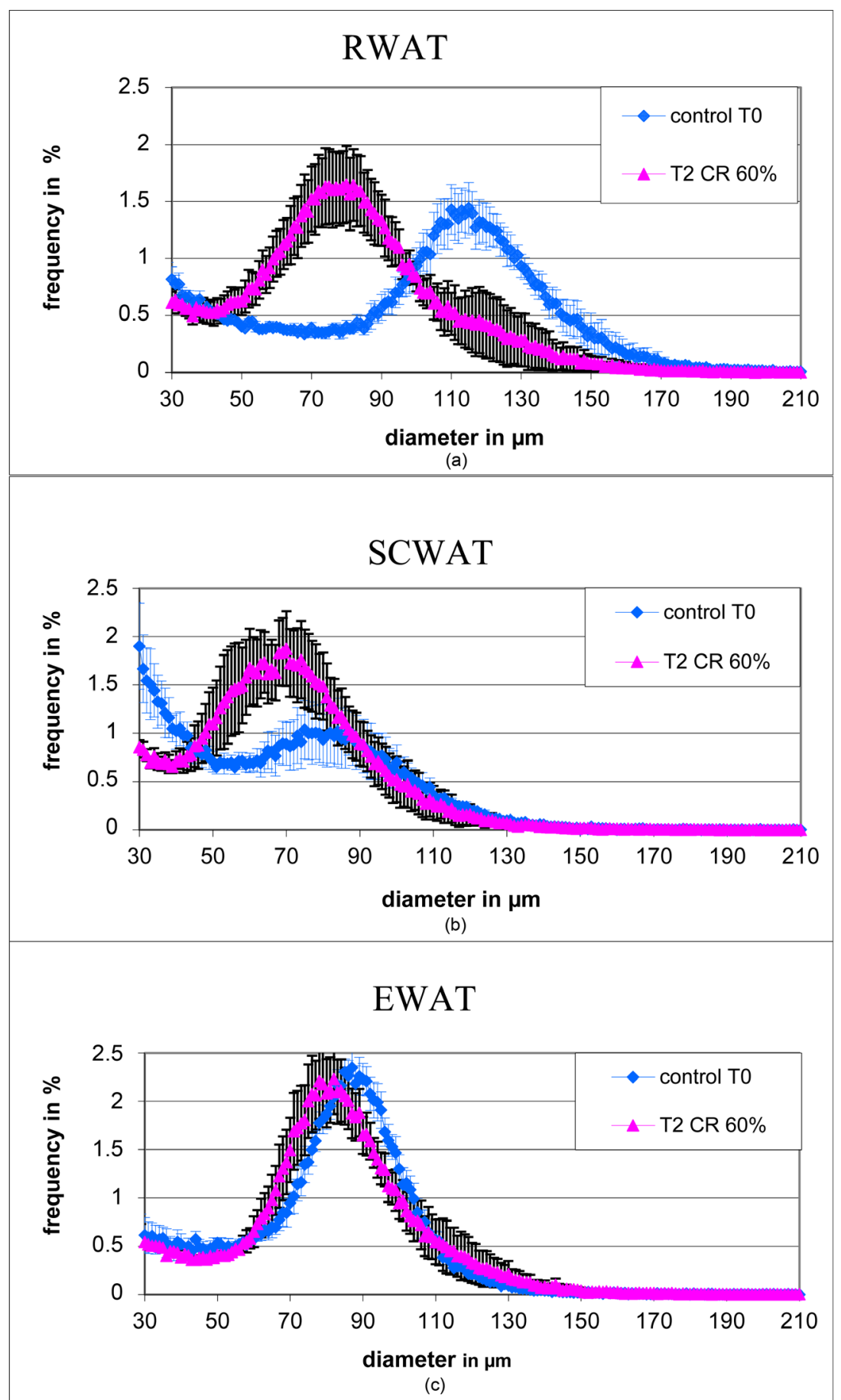

Figure 4. Comparison of adipose cell size repartition curves between control at T0 and calorie restricted animals at T2 in RWAT (a), SCWAT (b) and EWAT (c).

energy balance through first a rapid increase of adipose cell sizes followed by an increase in newly formed adipose cells if overfeeding last. It also means that when a subject initially overweighted has reached an ideal body mass after calorie restriction, he will have to continuously keep an eye on its calorie intake, at the risk if he does not, to start again immediately to gain weight and adipose tissue mass [17]. The conservation of adipose cell number during calorie restriction and fasting is most likely an adaptative mechanism, indeed evolution was typically associated with hunger and not with ad libitum feeding. It allows adipose tissue to regrowth as soon as the 
Table 1. Parameters of the cell size repartition curves in retroperitoneal [RWAT], epididymal [EWAT] and subcutaneous [SCWAT] adipose tissues in control ad libitum fed [A] and calorie restricted animals at 30\% [CR30\%] or 60\% [CR60\%], during the experimental protocol: T0 starting point, T1 after 37 days, T2 after 59 days.

\begin{tabular}{|c|c|c|c|c|}
\hline RWAT & mode & width & nadir & mean \\
\hline Control T0 & $108.4 \pm 3.0 \mathrm{~b}$ & $17.67 \pm 0.7 \mathrm{a}$ & $61.5 \pm 3.1 \mathrm{~b}$ & $91.0 \pm 2.3 b$ \\
\hline Control T1 & $116.6 \pm 9.3 \mathrm{c}$ & $21.2 \pm 2.1 \mathrm{~b}$ & $63.5 \pm 6.1 \mathrm{~b}$ & $97.2 \pm 7.0 \mathrm{c}$ \\
\hline Control T2 & $132.3 \pm 10.7 \mathrm{c}$ & $19.6 \pm 2.1 \mathrm{ab}$ & $75.2 \pm 7.7 \mathrm{~b}$ & $109.8 \pm 5.8 \mathrm{c}$ \\
\hline T2 CR30\% & $105.2 \pm 19.3$ bc & $15.8 \pm 2.8 \mathrm{a}$ & $61.7 \pm 9.6 \mathrm{~b}$ & $101.9 \pm 4.8 \mathrm{c}$ \\
\hline T2 CR60\% & $84.6 \pm 7.7 \mathrm{a}$ & $16.7 \pm 0.5 \mathrm{a}$ & $43.3 \pm 5.8 \mathrm{a}$ & $76.1 \pm 5.7 \mathrm{a}$ \\
\hline EWAT & mode & width & nadir & mean \\
\hline Control T0 & $87.4 \pm 0.9 \mathrm{a}$ & $12.3 \pm 1.2$ & $52.0 \pm 3.3 \mathrm{a}$ & $76.4 \pm 2.4 \mathrm{a}$ \\
\hline Control T1 & $110.5 \pm 5.4 \mathrm{ab}$ & $14.9 \pm 0.9$ & $65.0 \pm 3.6 \mathrm{ab}$ & $96.8 \pm 3.8 b$ \\
\hline Control T2 & $122.1 \pm 10.7 \mathrm{~b}$ & $14.3 \pm 0.9$ & $76.4 \pm 7.5 \mathrm{~b}$ & $100.1 \pm 8.0 \mathrm{~b}$ \\
\hline T2 CR30\% & $110.0 \pm 3.2 \mathrm{ab}$ & $12.1 \pm 1.9$ & $61.7 \pm 9.3 \mathrm{ab}$ & $85.5 \pm 6.6 \mathrm{ab}$ \\
\hline T2 CR60\% & $85.7 \pm 5.1 \mathrm{a}$ & $12.8 \pm 1.0$ & $48.8 \pm 2.9 \mathrm{a}$ & $77.6 \pm 3.5 \mathrm{a}$ \\
\hline SCWAT & mode & width & nadir & mean \\
\hline Control T0 & $82.3 \pm 0.8 \mathrm{ab}$ & $21.5 \pm 3.5 \mathrm{c}$ & $53.0 \pm 3.5 a b$ & $58.0 \pm 5.3 \mathrm{a}$ \\
\hline Control T1 & $106.0 \pm 2.1 \mathrm{c}$ & $16.3 \pm 3.9 \mathrm{bc}$ & $48.8 \pm 9.9 \mathrm{~b}$ & $80.7 \pm 7.3 \mathrm{~b}$ \\
\hline Control T2 & $100.6 \pm 10.9 \mathrm{c}$ & $19.4 \pm 3.3 \mathrm{bc}$ & $54.3 \pm 7.6 \mathrm{ab}$ & $78.4 \pm 1.4 \mathrm{~b}$ \\
\hline T2 CR30\% & $93.6 \pm 4.6$ bc & $12.5 \pm 1.9 \mathrm{ab}$ & $49.7 \pm 7.3 \mathrm{~b}$ & $76.8 \pm 4.0 \mathrm{~b}$ \\
\hline T2 CR60\% & $73.0 \pm 6.3 \mathrm{a}$ & $12.2 \pm 1.1 \mathrm{a}$ & $41.7 \pm 4.0 \mathrm{a}$ & $65.1 \pm 4.0 \mathrm{a}$ \\
\hline
\end{tabular}

caloric intake exceeds the daily energy expenditure. In times of recurrent food shortage, which was mostly the case during the emergence of Homo sapiens, the conservation of adipose cell number was an adaptative mechanism favouring survival. Hysteresis also explains the weight cycling effect [yo-yo effect] in reference to the cyclical loss and gain of body weight, during calorie restriction followed by uncontrolled food intake, resulting in a final body weight always higher than the initial body weight before diet restriction.

Several questions will have to be answered in the future. Fat accumulation is positively correlated with the intensity of oxidative stress in human and animal models [18] [19]. Calorie restriction diet improves insulin sensitivity, reduces circulating inflammation-related products and increases potent anti-inflammatory factors secreted by adipocytes [20]. Previous studies have suggested that the beneficial effect of dietary CR on glucose homeostasis can be attributed to a decrease in adipose cells and their products [21]. Several investigators have shown that large fat cells are linked to increased risk of developing type 2 diabetes [22] [23]. After Roux-en-Y gastric bypass a reduction in subcutaneous fat cell volume associates more strongly with improvement of insulin sensitivity than fat mass reduction per se [24]. More recent studies showed that subcutaneous adipose tissue morphology predicts improvements in insulin sensitivity after both short-term/moderate and long-term/pronounced weight reduction in obese subjects. Despite all these results, the relationship between the decrease in adipose mass, adipose cell size and the metabolic improvements are not well established and need to be clarified. Although the beneficial effect of calorie restriction has been well stated [25], the physiological and pharmacological properties of isolated adipose cells after weight reduction remains mainly unexplored. It is not known whether adipose cells after severe size reduction shares the same pharmacological responses than control adipose cells.

\section{Conclusion}

In conclusion, accumulation of visceral adipose tissue is a risk factor for a variety of metabolic alterations. Nu- 
merous studies have reported that fat mass reduction provides beneficial health effects, since the composition of adipose tissue is different before and after weight loss, the identification of the effect of adipose mass reduction on physiological regulation may bring new insights on the treatment of metabolic disease related to overweight and excess adipose tissue.

\section{Contribution Statement}

AG: design and conduction of the study, analysis and interpretation of data; statistical analysis of data, manuscript writing, study supervision.

HS: Analysis and interpretation of data; critical revision of the manuscript.

HL: performed the experiment, data collection.

EB: analysis of samples, analysis and interpretation of data, critical revision of the manuscript.

\section{References}

[1] Fasshauer, M. and Blüher, M. (2015) Adipokines in Health and Disease. Trends in Pharmacological Sciences, 36, 461-470. http://dx.doi.org/10.1016/j.tips.2015.04.014

[2] Zinder, O. and Shapiro, B. (1975) Effect of Cell Size on Epinephrine- and Acth-Induced Fatty Acid Release from Isolated Fat Cells. Journal of Lipid Research, 12, 91-95.

[3] Smith, U. (1971) Effect of Cell Size on Lipid Synthesis by Human Adipose Tissue in Vitro. Journal of Lipid Research, 12, 65-70.

[4] Gliemann, J. and Vinten, J. (1974) Lipogenesis and Insulin Sensitivity of Single Fat Cells. Journal of Physiology (London), 236, 499-516. http://dx.doi.org/10.1113/jphysiol.1974.sp010449

[5] Lafontan, M. and Berlan, M. (1995) Fat Cell Alpha 2-Adrenoceptors: The Regulation of Fat Cell Function and Lipolysis. Endocrine Reviews, 16, 716-738. http://dx.doi.org/10.1210/er.16.6.716

[6] Lay, S.L., Krief, S., Farnier, C., Lefrêre, I., Liepvre, X.L., Bazin, R., et al. (2001) Cholesterol, a Cell Size-Dependent Signal That Regulates Glucose Metabolism and Gene Expression in Adipocytes. Journal of Biological Chemistry, 276, 16904-16910. http://dx.doi.org/10.1074/jbc.M010955200

[7] Skurk, T., Alberti-Huber, C., Herder, C. and Hauner, H. (2007) Relationship between Adipocyte Size and Adipokine Expression and Secretion. Journal of Clinical Endocrinology \& Metabolism, 92, 1023-1033. http://dx.doi.org/10.1210/jc.2006-1055

[8] Wueest, S., Rapold, R.A., Rytka, J.M., Schoenle, E.J. and Konrad, D. (2009) Basal Lipolysis, Not the Degree of Insulin Resistance, Differentiates Large from Small Isolated Adipocytes in High-Fat Fed Mice. Diabetologia, 52, 541-546. http://dx.doi.org/10.1007/s00125-008-1223-5

[9] Miller, W.H., Faust, I.M., Goldberger, A.C. and Hirsch, J. (1983) Effects of Severe Long-Term Food Deprivation and Refeeding on Adipose Tissue Cells in the Rat. American Journal of Physiology, 245, E74-E80.

[10] Géloën, A., Roy, P.E. and Bukowiecki, L.J. (1989) Regression of White Adipose Tissue in Diabetic Rats. American Journal of Physiology, 257, E547-E553.

[11] Di Girolamo, M., Fine, J.B., Tagra, K. and Rossmanith, R. (1998) Qualitative Regional Differences in Adipose Tissue Growth and Cellularity in Male Wistar Rats Fed Ad Libitum. American Journal of Physiology, 274, R1460-R1467.

[12] Hadji, L., Berger, E., Soula, H., Vidal, H. and Géloën, A. (2014) White Adipose Tissue Resilience to Insulin Deprivation and Replacement. PLoS ONE, 9, e106214. http://dx.doi.org/10.1371/journal.pone.0106214

[13] Soula, H.A., Julienne, H., Soulage, C.O. and Géloën, A. (2013) Modelling Adipocytes Size Distribution. Journal of Theoretical Biology, 332, 89-95. http://dx.doi.org/10.1016/j.jtbi.2013.04.025

[14] Soula, H.A., Géloën, A. and Soulage, C.O. (2015) Model of Adipose Tissue Cellularity Dynamics during Food Restriction. Journal of Theoretical Biology, 364, 189-196. http://dx.doi.org/10.1016/j.jtbi.2014.08.046

[15] Bailey, J.W., Barker, R.L. and Beauchene, R.E. (1993) Age-Related Changes in Rat Adipose Tissue Cellularity Are Altered by Dietary Restriction and Exercise. Journal of Nutrition, 123, 52-58.

[16] Ghorbani, A., Varedi, M., Hadjzadeh, M.A. and Omrani, G.H. (2010) Type-1 Diabetes Induces Depot-Specific Alterations in Adipocyte Diameter and Mass of Adipose Tissues in the Rat. Experimental and Clinical Endocrinology \& Diabetes, 118, 442-448. http://dx.doi.org/10.1055/s-0030-1247566

[17] Kirchner, H., Hofmann, S.M., Fischer-Rosinský, A., Hembree, J., Abplanalp, W., Ottaway, N., et al. (2012) Caloric Restriction Chronically Impairs Metabolic Programming in Mice. Diabetes, 61, 2734-2742.

[18] Furukawa, S.H., Fujita, T., Shimabukuro, M., Iwaki, M., Yamada, Y., Nakajima, Y., et al. (2004) Increased Oxidative 
Stress in Obesity and Its Impact on Metabolic Syndrome. The Journal of Clinical Investigation, 114, 1752-1761. http://dx.doi.org/10.1172/JCI21625

[19] Ramos, L.F., Shintani, A., Ikizler, T.A. and Himmelfarb, J. (2008) Oxidative Stress and Inflammation Are Associated with Adiposity in Moderate to Severe CKD. Journal of the American Society of Nephrology, 19, 593-599. http://dx.doi.org/10.1681/ASN.2007030355

[20] Park, S., Park, N.Y., Valacchi, G. and Lim, Y. (2012) Calorie Restriction with a High-Fat Diet Effectively Attenuated Inflammatory Response and Oxidative Stress-Related Markers in Obese Tissues of the High Diet Fed Rats. Mediators of Inflammation, 2012, Article ID: 984643. http://dx.doi.org/10.1155/2012/984643

[21] Barzilai, N. and Gabriely, I. (2001) The Role of Fat Depletion in the Biological Benefits of Caloric Restriction. The Journal of Nutrition, 131, 903S-906S.

[22] Weyer, C., Foley, J.E., Bogardus, C., Tataranni, P.A. and Pratley, R.E. (2000) Enlarged Subcutaneous Abdominal Adipocyte Size, but Not Obesity Itself, Predicts Type II Diabetes Independent of Insulin Resistance. Diabetologia, 43, 1498-1506. http://dx.doi.org/10.1007/s001250051560

[23] Lonn, M., Mehlig, K., Bengtsson, C. and Lissner, L. (2010) Adipocyte Size Predicts Incidence of Type 2 Diabetes in Women. The FASEB Journal, 24, 326-331. http://dx.doi.org/10.1096/fj.09-133058

[24] Andersson, D.P., Eriksson Hogling, D., Thorell, A., Toft, E., Qvisth, V., Naslund, E., et al. (2014) Changes in Subcutaneous Fat Cell Volume and Insulin Sensitivity after Weight Loss. Diabetes Care, 37, 1831-1836. http://dx.doi.org/10.2337/dc13-2395

[25] Clément, K., Viguerie, N., Poitou, C., Carette, C., Pelloux, V., Curat, C.A., et al. (2004) Weight Loss Regulates Inflammation-Related Genes in White Adipose Tissue of Obese Subjects. The FASEB Journal, 18, 1657-1669. http://dx.doi.org/10.1096/fj.04-2204com 